Маланчук Л. О. [1; ORCID ID: 0000-0002-6341-5639], к.е.н., доцент,

Жакун Ю. В. [1; ORCID ID: 0000-0003-2532-7088], здобувач вищої освіти другого (магістерського) рівня

${ }^{1}$ Національний університет водного господарства та природокористування, м. Рівне

\title{
АНАЛІЗ СИСТЕМИ ЕЛЕКТРОННОГО ДОКУМЕНТООБІГУ В ДЕРЖАВНИХ УСТАНОВАХ ТА ШЛЯХИ ЇЇ ВДОСКОНАЛЕННЯ
}

У статті досліджуються особливості електронного документообігу, його переваги та недоліки. Проаналізовано наявне нормативно-правове забезпечення функціонування системи. Наведено основні відмінності між паперовою системою документації та системою електронного документообігу. Визначено основні завдання, які повинні виконуватися в ході використання системи електронного врядування. На основі встановлення та систематизації існуючих проблем запропоновано шляхи їх вирішення та вдосконалення системи електронного документообігу в державній установі.

Ключові слова: документація; державні органи; нормативні документи; документообіг; інформація.

\section{Вступ}

Одним із головних питань в середовищі електронного урядування $€$ перехід на електронну форму ведення діловодства та документообігу в державних установах, органах місцевого самоврядування (доступ до державної інформації, можливість здійснення більшості стандартних операцій між громадськістю, громадянином і бізнесом). У результаті відбулося зростання ролі електронних документів, а використання традиційних паперових копій почало поступово зменшуватися. Тому на сьогоднішній день активно розробляється та удосконалюється нормативно-правова база документообігу, створюються покращені електронні послуги 3 використанням електронного підпису, який забезпечує правову базу електронних документів.

Застосування електронного документообігу дає можливість скоротити витрати праці та часу на опрацювання документів, прийняття рішень, підвищення виконавської дисципліни та спрощення механізму контролю в управлінні, покращити 
функціонування систем надання послуг населенню, доступ до інформації про діяльність державних органів та органів місцевого самоврядування, удосконалити відносини з підлеглими та іншими організаціями і досягти певної економічної ефективності.

\section{Аналіз останніх досліджень}

Найбільш вагомий внесок у вивчення сучасних проблем стану інформаційного забезпечення державного управління здійснили Бакаєв Л.О., Берсуцький Я.Г., Глушков В.М., Калюжний Р.А., Писаревська Т.А., Ситник В.Ф. та ін. У працях цих науковців розглянуті принципи формування ефективної системи документообігу в державних установах. Також варто зауважити, що значна увага питанням формування інформаційного забезпечення в системі державного управління приділялася Клименком І.В., Лисенком Ю.Г., Осауленком О.Г., Панчуком А.М., Ралдугіном Є.О., Сендзюк М.А. Завдяки інноваціям та електронному уряду управління в усьому світі може бути ефективнішим, надавати кращі послуги, відповідати на вимоги громадян щодо прозорості та підзвітності.

\section{Мета та завдання дослідження}

Мета даної роботи полягає у дослідженні сфери електронного документообігу в державних установах як системи здійснення широкого спектру взаємодії з громадянами та бізнесом, відкритих державних даних, а також забезпечення інновацій в управлінні.

Завданнями цієї роботи $\epsilon$ розгляд існуючих переваг та недоліків системи електронного документообігу, визначення найоптимальніших та найефективніших шляхів вдосконалення вже існуючої системи електронного урядування, а також підтвердження того факту, що вона удосконалює процеси обігу документації та економить час користувачів.

\section{Виклад основного матеріалу}

Державні установи мають унікальну безпосередню взаємодію 3 громадянами. Відносини між ними та громадянами неминучі: наприклад, реєстрація підприємств, автореєстрація, реальний державний розвиток чи навіть абонемент дитини в школу - все це вимагає від громадян контакту 3 державною установою. Метою електронного урядування $€$ створення нових динамічних відносин між урядами та громадянами: цикл, який стане простішим та більш активним для громадян. Для досягнення цього важливо не лише впровадження технологій у звичайні завдання установ, а й в управління державним сектором, причому громадяни $\epsilon$ центром цієї інновації [4].

Папір дає можливість зберігати дані, але не полегшує 
використання цих даних. Напевно, всі ми стикалися з тим, що не могли знайти потрібні файли, тому що вони не там, де ми думали, що вони повинні бути. Іноді потрібні години, щоб відстежити інформацію в паперових файлах, і це якщо ми взагалі зможемо їі знайти. Коли ми зберігаємо документи в електронному вигляді в будь-якій системі, то можемо здійснювати повнотекстовий пошук усіх своїх файлів. Це дозволяє швидко та легко знайти саме те, що потрібно.

На додаток до економії часу та організаційних переваг електронного документообігу, цифровий спосіб також заощаджує простір, оскільки займає набагато менше місця для зберігання ніж паперові файли в коробках і шафах для документів. Крім того, збереження в цифровому вигляді означає те, що створювати резервні копії файлів набагато легше. Також немає небезпеки, що пожежа, повінь чи інші стихійні лиха знищать паперові файли. До того ж відбувається більш ефективне управління завдяки автоматичному моніторингу впровадження прозорості в усій установі на всіх рівнях, підтримка ефективного зберігання, управління та доступу до інформації та знань, забезпечується гнучкість персоналу за рахунок більшої формалізації кожного працівника та можливості збереження всієї історії його діяльності.

Нарешті, перехід на цифровий документообіг - це ще один крок до «зеленого» безпаперового офісу. Крім того, ви також не платите за місце для зберігання великих паперових файлів. I не витрачаєте час (а отже, гроші) на те, щоб упорядкувати ці файли та намагатися їх сортувати, коли вам потрібно знайти документи [2].

Стрімкий розвиток суспільства та суспільних відносин став головним важелем у розробці, вдосконаленні та оновленні нормативно-правової бази України у сфері електронного урядування, створенні спеціальних юридичних принципів та норм регулювання сфери електронного документообігу. Саме тому Верховною Радою України були прийняті закони України «Про електронні документи та електронний документообіг», «Про електронний цифровий підпис», «Про обов'язковий примірник документів», «Про Національну програму інформатизації», «Про телекомунікації», «Про Національну систему конфіденційного зв'язку», «Про захист інформації в інформаційно-телекомунікаційних системах» тощо [1].

Варто зауважити, що за даними ООН Україна у 2008 році посідала 41 місце у рейтингу з 193 країн за рівнем готовності до електронного уряду за індексом EGDI. Протягом 12 років позиція у рейтингу підіймалася і опускалася. У 2020 році країна покращила свої позиції, змістилася у списку і зайняла 69 місце у світі (рис. 1). Тобто Україна тільки почала поступово підніматися у світовому 
рейтингу, а це передбачає покращення електронного документообігу в усіх установах, у тому числі й в органах державної влади.

Така ситуація дає поштовх державним установам удосконалити систему електронного документообігу, зокрема, у Міністерстві цифрової трансформації запустили онлайн-платформу «ВзаємоДія» за підтримки Програми EGAP, що реалізується Фондом Східна Європа, підтримали ініціативу Президента України Володимира Зеленського щодо запровадження інтернет-голосування на виборах та референдумах, сформували Концепцію цифрової трансформації громад та надають свої пропозиції до законопроєкту «Про публічні консультації», розробленого Мін'юстом. Вже у 2022 році ми прагнемо увійти до двадцятки країн рейтингу, а це показник того, що розвиток системи справді відбувається, більше того - дає хороші результати.

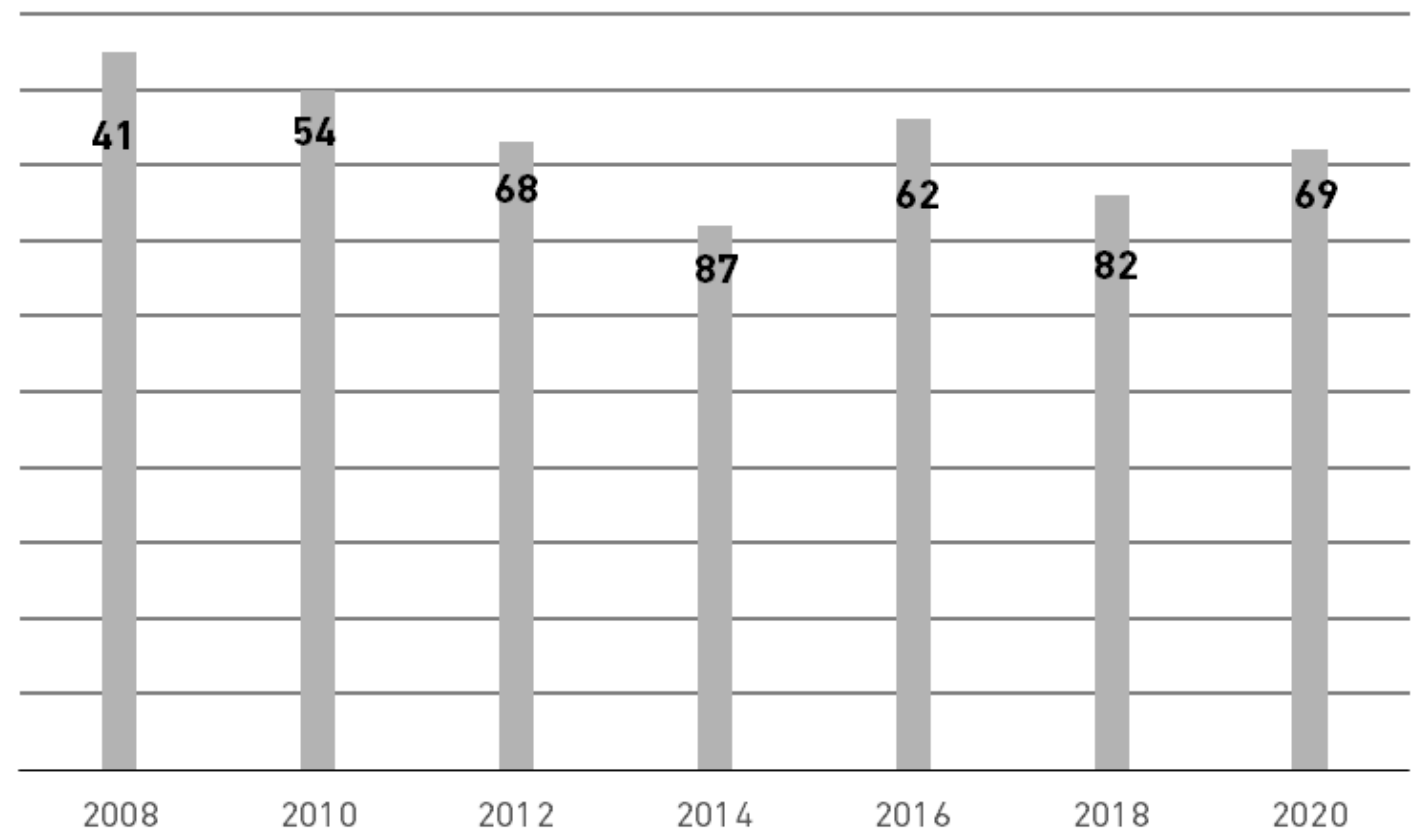

Рис. 1. Місце України у світовому рейтингу щодо готовності до діяльності електронного уряду [6]

Незважаючи на те що електронний документообіг допомагає вирішити деякі проблеми (наприклад, мінімізує ризик того, що файли стануть непотрібними під час повені), воно не повністю вирішує перешкоди управління даними, з якими установи все ще стикаються щодня. $€$ ще декілька значущих проблем, коли йдеться про керування документацією.

Такими можна вважати нав'язування рішення вищими органами влади без рекомендованої уніфікованої методології впровадження; потенційну необхідність адаптації або заміни 
розробленого рішення найближчим часом на інше, типове програмне забезпечення; консерватизм персоналу, низький рівень освіти, небажання навчатися та перекваліфіковуватися, а також страх вищого керівництва перед прозорістю власної діяльності, який виникає після впровадження систем електронного документообігу; електронні документи можуть зазнати збою або ж можуть бути пошкоджені; неузгодженість між спеціалістами інформаційних технологій та служб діловодства; постійні структурні зміни в організації; небажання модифікувати наявні процеси діловодства 3 метою переходу до автоматизованих систем тощо [5].

Проте пам'ятаємо, що електронний документообіг - це високотехнологічний і прогресивний підхід до суттєвого підвищення ефективності роботи органів державної влади і місцевого самоврядування, і вагомих переваг він має насправді більше ніж недоліків (рис. 2).

\begin{tabular}{|c|}
\hline Переваги впровадження СЕД \\
\hline дина база всіх документів для централізованого зберігання \\
\hline Персональний кабінет документів \\
\hline Паралельне виконання різних операцій над документами \\
\hline Єдиний шаблон документів \\
\hline Швидкий процес передачі, узгодження інформації \\
\hline Історія редагування документу \\
\hline Економія паперу \\
\hline Швидкий пошук документів в єдиному архіві \\
\hline Кваліфікований електронний підпис \\
\hline Можливість вміщення в документ мультимедійних даних \\
\hline
\end{tabular}

Рис. 2. Переваги впровадження системи електронного документообігу [3]

На основі встановлення та систематизації існуючих проблем впровадження системи електронного документообігу в державних установах та органах місцевого самоврядування встановлено, що задля ефективнішої роботи варто мінімізувати кількість існуючих недоліків системи та проведено аналіз можливих шляхів вирішення більшості із них (рис. 3). 


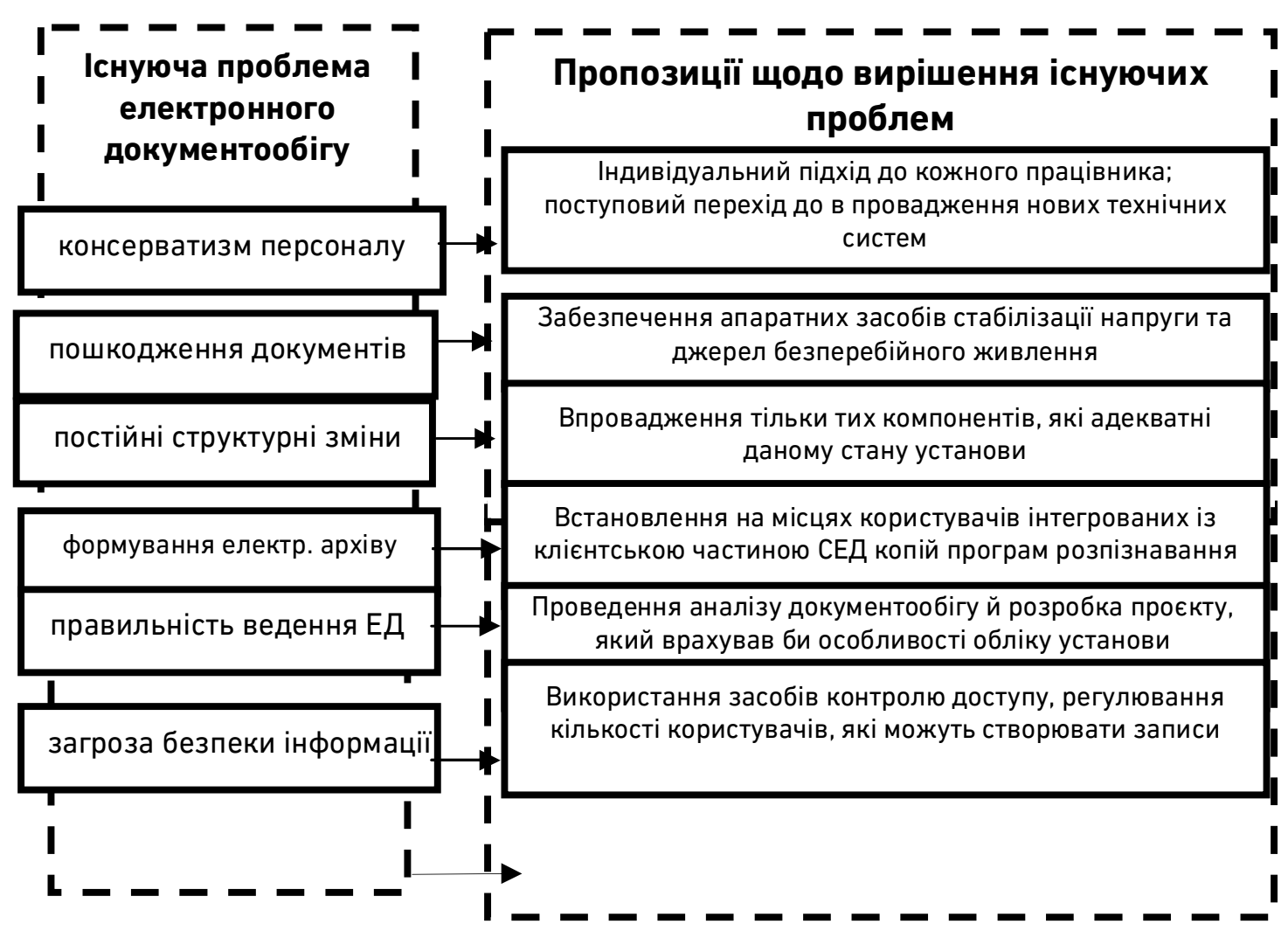

Рис. 3. Шляхи вирішення можливих проблем СЕД в державній установі

Таким чином бачимо, що упорядкування електронних документів дає державних установам (і не тільки) значні економічні вигоди, але його якісна оцінка $€$ складним процесом, оскільки доводиться враховувати багато факторів.

\section{Висновки}

Отже, можемо зробити висновок, що перехід від паперових документів до системи електронного документообігу - це не просто данина модній тенденції цифровізації, а потужний інструмент підвищення продуктивності роботи державних установ, що $\epsilon$, безсумнівно, вигідним для нас, як для користувачів їхніх послуг.

Хоча створення системи управління документами, безумовно, $\epsilon$ початковим кроком у правильному напрямку, неорганізована або погано керована система ділових документів може призвести до різноманітних проблем, 3 якими наразі стикаються системи керування документами, починаючи від оновленості та відповідності всім правилам ведення записів галузі, до контролю ризиків безпеки установи. Для цього необхідно реалізувати ряд шляхів удосконалення існуючої системи документообігу для того, що мінімізувати ризики їі неефективності та ще раз упевнитися, що це чудова альтернатива паперовій документації. 
1. Електронний документообіг та захист інформації : навч. посіб. / за ред. Н. В. Грицяк. НАДУ, 2015. 84 с. 2. Інформаційно-аналітичне забезпечення органів місцевої влади : навч. посіб. / за ред. В. М. Дрешпака. Дніпропетровськ : ДРІДУ НАДУ, 2014. 160 с. 3. Копняк К. В., Покиньчереда В. В. Електронний документообіг в публічному управлінні: проблеми впровадження, переваги та перспективи. URL: http://www.dy.nayka.com.ua/pdf/10 2020/37.pdf (дата звернення: 10.09.2021). 4. Матвієнко О. В. Основи організації електронного документообігу : навч. посіб. К. : Центр учбової л-ри, 2018. 111 с. 5. Олуйко В. Інформаційне забезпечення державної служби. Менеджер. 2013. № 2 (24). С. 12-17. 6. UN E-Government Knowledgebase. Country Data (2020). URL: https://publicadministration.un.org/egovkb/en-us/Data-Center (дата звернення: 10.09.2021).

\section{REFERENCES:}

1. Elektronnyi dokumentoobih ta zakhyst informatsii : navch. posib. / za red. N. V. Hrytsiak. NADU, 2015. 84 s. 2. Informatsiino-analitychne zabezpechennia orhaniv mistsevoi vlady : navch. posib. / za red. V. M. Dreshpaka. Dnipropetrovsk : DRIDU NADU, 2014. 160 s. 3. Kopniak K. V., Pokynchereda V. V. Elektronnyi dokumentoobih v publichnomu upravlinni: problemy vprovadzhennia, perevahy ta perspektyvy. URL: http://www.dy.nayka.com.ua/pdf/10_2020/37.pdf (data zvernennia: 10.09.2021). 4. Matviienko O. V. Osnovy orhanizatsii elektronnoho dokumentoobihu : navch. posib. K. : Tsentr uchbovoi l-ry, 2018. 111 s. 5. Oluiko V. Informatsiine zabezpechennia derzhavnoi sluzhby. Menedzher. 2013. № 2 (24). S. 12-17. 6. UN E-Government Knowledgebase. Country Data (2020). URL: https://publicadministration.un.org/egovkb/en-us/Data-Center (data zvernennia: 10.09.2021).

Malanchuk L. O. [1; ORCID ID: 0000-0002-6341-5639], Candidate of Economics (Ph.D.), Associate Professor, Zhakun Yu. V. [1; ORCID ID: 0000-0003-2532-7088], Master

${ }^{1}$ National University of Water and Environmental Engineering, Rivne

\section{ANALYSIS OF THE ELECTRONIC DOCUMENT FLOW SYSTEM IN GOVERNMENT INSTITUTIONS AND WAYS OF ITS IMPROVEMENT}

The article examines electronic document management as an information system that provides the process of creating, controlling access and distribution of electronic documents, as well as provides control over the flow of documents in the organization that operates in government agencies. Its features, advantages, in particular the possibility of placing 
multimedia data in the document, qualified electronic signature, fast search of documents in a single archive, fast transfer process, coordination of information, etc., and disadvantages (conservatism of staff, document damage in case of system failures, constant structural changes, threat to information security). The existing regulatory and legal support for the functioning of the system is analyzed. The main differences between the paper documentation system and the electronic document management system are given. The main tasks to be performed during the use of egovernment are identified. The statistical data concerning Ukraine's place in the world rating on readiness for e-government activity are given (in 2020 , the country improved its position, moved up the list and ranked 69th in the world, ie Ukraine has only begun to gradually rise in the world rankings, which means improving electronic document management in all institutions, including public authorities). Based on the establishment and systematization of existing problems, ways to solve them and improve the system of electronic document management in a public institution, in particular, an individual approach to each employee; gradual transition to the introduction of new technical systems, providing hardware stabilization of voltage and sources of uninterrupted life, the introduction of only those components that are adequate to the state of the institution, the use of access controls, regulating the number of users who can create records and so on.

Keywords: documentation; state bodies; normative documents; document circulation; information; digitization.

Маланчук Л. А. [1; ORCID ID: 0000-0002-6341-5639], К.э.Н., доцент,

Жакун Ю. В. [1; ORCID ID: 0000-0003-2532-7088], соискатель высшего образования второго (магистерского) уровня

${ }^{1}$ Национальный университет водного хозяйства и природопользования, Ровно

\section{АНАЛИЗ СИСТЕМЫ ЭЛЕКТРОННОГО ДОКУМЕНТООБРАЩЕНИЯ В ГОСУДАРСТВЕННЫХ УЧРЕЖДЕНИЯХ И ПУТИ ЕЕ СОВЕРШЕНСТВОВАНИЕ}

В статье исследуются особенности электронного документооборота, его преимущества и недостатки. Проанализировано существующее нормативно-правовое обеспечение функционирования системы. Приведены основные отличия между бумажной системой документации и системой электронного документооборота. Определены основные 80 
задачи, которые должны выполняться при использовании системы электронного управления. На основе установления и систематизации существующих проблем предложены пути их решения и усовершенствования системы электронного документооборота в государственном учреждении.

Ключевые слова: документация; государственные органы; нормативные документы; документооборот; информация.

Отримано: 11 вересня 2021 р. Прорецензовано: 16 вересня 2021 р. Прийнято до друку: 24 вересня 2021 р. 